\title{
Neuroimaging in myotonic dystrophy type 1
}

\begin{tabular}{|ll|}
\hline Figure 1 & $\begin{array}{l}\text { Axial fluid-attenuated inversion recovery } \\
\text { image shows symmetric, confluent } \\
\text { signal hyperintensity in the anterior } \\
\text { temporal lobe white matter }\end{array}$ \\
\end{tabular}

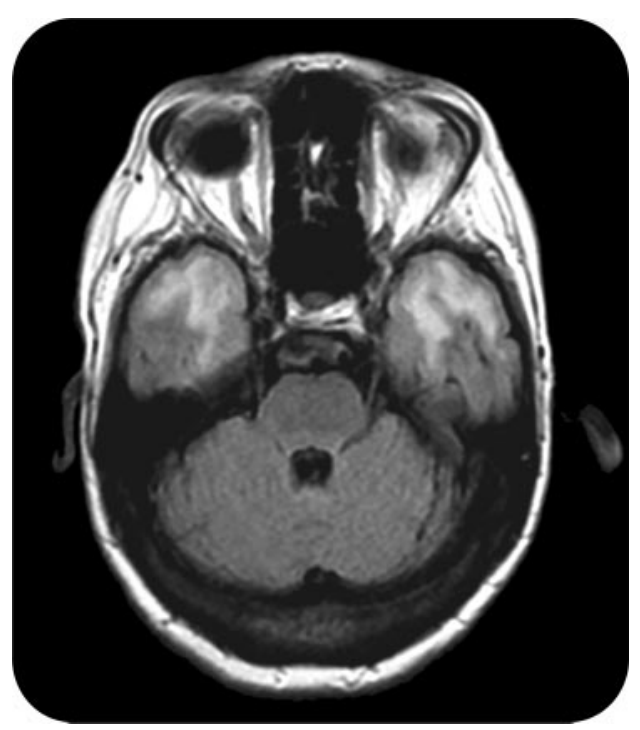

Figure 2 Small basal angle (craniokyphosis), prominent frontal sinus, and diffuse thickening of the skull with ossification of the falx is noted on sagittal T1-weighted images

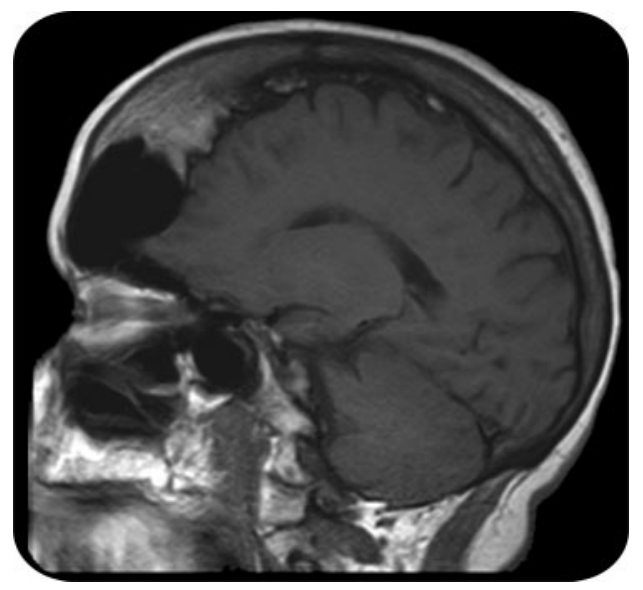

A 56-year-old woman with a 10-year history of myotonic dystrophy type 1 (MD) presented with progressive lower extremity weakness. MRI showed multiple discrete and confluent areas of abnormal signal intensity throughout the subcortical white matter with predominant involvement of the frontal and anterior temporal lobes (figure 1).

The confluent white matter lesions in the anterior temporal lobes seen in MD can be radiologically confused with cerebral autosomal dominant arteriopathy with subcortical infarcts and leukoencephalopathy (CADASIL). Unlike CADASIL, MD also displays skull abnormalities (figure 2). ${ }^{1,2}$ Both syndromes should be considered in patients with confluent temporal lobe lesions on MRI.

Laurence A. Donahue, BA, Rajiv Mangla, MD, Per-Lennart Westesson, MD, DDS, PhD, Rochester, NY Disclosure: The authors report no disclosures.

Address correspondence and reprint requests to Laurence A. Donahue, Medical Student, University of Rochester School of Medicine and Dentistry, Rochester, NY 14620; Laurence_Donahue@urmc.rochester.edu

1. Miaux Y, Chiras J, Eymard B, et al. Cranial MRI findings in myotonic dystrophy. Neuroradiology 1997;39:166-170.

2. Chabriat H, Joutel A, Dichgans M, Tournier-Lasserve E, Bousser MG. CADASIL. Lancet Neurol 2009;8:643-653. 


\title{
Neurology
}

\author{
Neuroimaging in myotonic dystrophy type 1 \\ Laurence A. Donahue, Rajiv Mangla and Per-Lennart Westesson \\ Neurology 2009;73;1931 \\ DOI 10.1212/WNL.0b013e3181c3fdb0
}

This information is current as of November 30, 2009

\section{Updated Information \&}

Services

References

Subspecialty Collections

Permissions \& Licensing

Reprints including high resolution figures, can be found at: http://n.neurology.org/content/73/22/1931.full

This article cites 2 articles, 0 of which you can access for free at: http://n.neurology.org/content/73/22/1931.full\#ref-list-1

This article, along with others on similar topics, appears in the following collection(s):

CADASIL

http://n.neurology.org/cgi/collection/cadasil

Motor Control

http://n.neurology.org/cgi/collection/motor_control

MRI

http://n.neurology.org/cgi/collection/mri

Muscle disease

http://n.neurology.org/cgi/collection/muscle_disease

Information about reproducing this article in parts (figures,tables) or in its entirety can be found online at:

http://www.neurology.org/about/about_the_journal\#permissions

Information about ordering reprints can be found online:

http://n.neurology.org/subscribers/advertise

Neurology ${ }^{\circledR}$ is the official journal of the American Academy of Neurology. Published continuously since 1951, it is now a weekly with 48 issues per year. Copyright . All rights reserved. Print ISSN: 0028-3878. Online ISSN: 1526-632X.

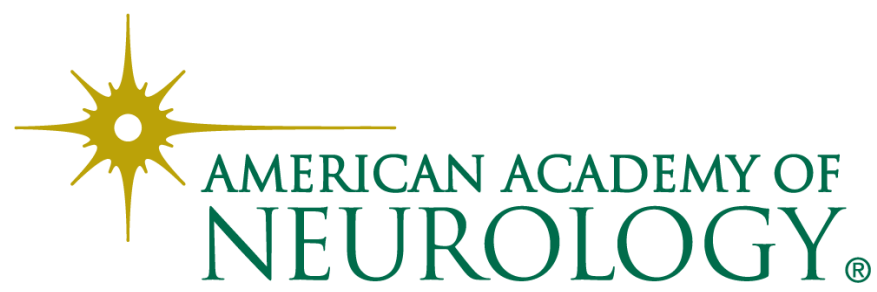

